\title{
Innate Immunity in ALS
}

\author{
John D. Lee1, Jia Y. Lee'1, Stephen M. Taylor ${ }^{1}$, \\ Peter G. Noakes ${ }^{1,2}$ and Trent M. Woodruff ${ }^{1}$ \\ ${ }^{1}$ School of Biomedical Sciences, \\ ${ }^{2}$ Queensland Brain Institute, University of Queensland, \\ Australia
}

\section{Introduction}

Amyotrophic Lateral Sclerosis (ALS), also known as Lou Gehrig's disease, is the most common form of motor neuron disease. It is a debilitating, late onset neurodegenerative disorder that is characterized by the progressive death of upper and a-motor neurons within the central nervous system (CNS) (Bruijn and Cleveland, 1996). This results in symptoms of muscle weakness and atrophy of skeletal muscles, leading to paralysis and eventual death due to failure of respiratory muscles (Cozzolino et al., 2008). ALS has a prevalence of approximately $1 \sim 2$ per 100,000 worldwide with males being more susceptible than females $(1.3 \sim 1.6: 1)$ (Strong, 2003, Woodruff et al., 2008b, Worms, 2001). The majority of ALS cases $(\sim 90 \%)$ are thought to be sporadic with unknown aetiology and no robust environmental risk factors, with the remaining $10 \%$ being familial ALS. Of this $10 \%$, approximately $20 \%$ have been linked to dominant mis-sense point mutations in the Copper/Zinc superoxide dismutase 1 (SOD1) gene which results in a gain of unidentified deleterious properties (Rosen et al., 1993). The two aetiologies of ALS (i.e. sporadic and familial) are indistinguishable on the basis of their clinical and pathological features, including progressive muscle weakness, atrophy and spasticity, each of which reflects the degeneration and death of upper and a-motor neurons (Boillee et al., 2006). The mechanisms leading to ALS are still unclear but theories have suggested that glutamate excitoxicity, oxidative stress, protein aggregation, mitochondrial dysfunction, cytoskeletal abnormalities and neuro-inflammation may all play a role (Bruijn et al., 2004). The present chapter will review the role of innate immune system, in particular the complement system, during the disease progression of ALS. It will review evidence for an involvement of the innate immune Toll-like receptor (TLR) system and receptor for advanced glycosylation end products (RAGE) in ALS patients and animal models of ALS. It will also comprehensively evaluate the role of the innate immune complement cascade in this disease. Finally, the future therapeutic possibilities for ALS, aimed at targeting components of the innate immune system will be discussed. We provide compelling evidence for specific inhibitors of complement C5a receptors as novel treatment strategies for ALS.

\section{Innate immunity in neurodegenerative disease}

Innate immunity is an evolutionary ancient system that provides the host with immediately available defence mechanisms. It is a rapid and coordinated cascade of reactions by host 
cells to protect them against foreign pathogens and insults (Akira et al., 2001, Nguyen et al., 2004). Until recently, the CNS was considered to be immunologically privileged because of its inability to mount an immune response and process antigens. Recent studies have revealed that immune surveillance and differentiation between self and non-self does take place in the CNS, where glial cells, including microglia, astrocytes and oligodendrocytes, act as CNS immune effector cells (Hanisch et al., 2008, Lehnardt, 2010, Ricklin et al., 2010).

The role of innate immune system in the CNS is mainly to provide protection to the neurons from foreign pathogens and injurious stimuli, and to maintain CNS homeostasis. It is also required for tissue modelling during development and following injury (Benard et al., 2008, Mastellos et al., 2005, Rahpeymai et al., 2006, Stevens et al., 2007). However sustained chronic inflammation might be harmful for neuronal integrity and may result in cellular dysfunction which triggers neurodegeneration. There is increasing evidence that suggests an involvement of the innate immune system in the development of neuro-inflammation which may drive the progression of many neurodegenerative diseases including ALS. Two major constituents of innate immune system are the TLRs and the complement cascade, each of which are described below.

\section{Toll-like receptors (TLRs) and receptor for advanced glycosylation end products (RAGE) in ALS}

TLRs are a large family of evolutionarily conserved transmembrane glycoproteins that initiate immune responses for host defence upon activation. These receptors are pattern recognition receptors that recognise pathogen-associated molecular patterns (PAMPs) from diverse organisms including bacteria, viruses, fungi and parasites (Liew et al., 2005). TLRs are expressed in various cell types in the CNS including microglia, astrocytes, oligodendrocytes and neurons (Aravalli et al., 2007, Bowman et al., 2003, Olson and Miller, 2004, Tang et al., 2007). This pathway has recently been implicated in the pathogenesis of ALS. Increased levels of TLRs (TLR1, TLR2, TLR5, TLR7 and TLR9) have been observed in mutant SOD1 mice as compared to controls (Letiembre et al., 2009) and mutant SOD1 expression in ALS has been suggested to facilitate microglial neurotoxic inflammatory responses via TLR2 (Liu et al., 2009). In addition, it has recently been shown that mutant SOD1 binds to CD14, which is a co-receptor of TLR2 and TLR4, and that microglial activation mediated by mutant SOD1 (G93A) can be attenuated using TLR2, TLR4 and CD14 blocking antibodies (Zhao et al., 2010). The involvement of TLR signalling in the pathogenesis of ALS is also supported by up-regulation of TLR2 and TLR4 mRNA and protein in the ALS patients, compared to control spinal cords. The increased expression level of TLR2 and TLR4 was shown on microglia and reactive astrocytes respectively (Casula et al., 2011). This suggests that TLRs could play a role in the progressive degeneration of motor neurons in ALS and indicates that the innate immune system is important in sensing neuronal injury and driving the progression of this disease.

In absence of pathogens, TLR signalling can also be activated via molecules called damage associated molecular patterns (DAMPs) including the high mobility group box 1 (HMGB1) protein released by injured tissues (Bianchi and Manfredi, 2009). HMGB1 is a nearly ubiquitous chromatin component that can regulate transcription of different sets of genes, including proinflammatory genes (Bianchi and Manfredi, 2009, Mouri et al., 2008). It can also be released passively by necrotic cells and actively secreted by stimulated monocytes/macrophages and astrocytes, which then bind to RAGE, TLR2 and TLR4. (Andersson et al., 2008, Hreggvidsdottir 
et al., 2009, Parker et al., 2004, Scaffidi et al., 2002). Therefore, HMGB1 can act as a potent proinflammatory cytokine-like mediator, thus contributing to amplification of the inflammatory response (Bianchi and Manfredi, 2007, Hreggvidsdottir et al., 2009). HMGB1-RAGE signalling has also been implicated in the progression of ALS where there was a significant increase in HMGB1 mRNA expression in ALS patient spinal cords when compared to normal individuals (Casula et al., 2011). The increased expression of HMGB1 was expressed by activated microglia and astrocytes in the spinal cord (Casula et al., 2011). Interestingly, there were no significant changes in RAGE mRNA expression in 12 ALS patients when compared to 6 controls. This observation could be due to the loss of motor neurons expressing RAGE in ALS patients, thus reducing the endogenous pool of RAGE mRNA. This same study also demonstrated that there is an increased expression of RAGE on astrocytes and microglia when compared to controls (Casula et al., 2011). Furthermore, serum soluble RAGE (sRAGE) levels were decreased in the serum of ALS patients when compared to normal individuals, where sRAGE is known to be a possible modulator of inflammation in several diseases (Ilzecka, 2009). Hence it is possible that low sRAGE levels may accelerate the neurodegeneration and could be a risk factor in ALS. This suggests that TLR/RAGE signalling may play a role in the disease progression of ALS, by activating microglia and astrocytes in the vicinity of motor neuron death. Targeting TLRs and RAGE may therefore be a novel therapeutic strategy to treat degenerative neuronal loss occurring in ALS.

\section{The complement system in the CNS}

The complement system is a key component of the innate immune system, which participates in the recognition, trafficking and elimination of pathogens and unwanted host materials. The complement system is an enzymatic cascade consisting of more than 30 plasma proteins and glycoproteins, and either soluble or membrane-bound receptors (Guo and Ward, 2005). Complement activation participates in host defence against pathogens primarily by cytotoxic and cytolytic activity through triggering formation of the membrane attack complex (MAC or C5b-9) on the target cell membrane (van Beek et al., 2003). It is activated via three major pathways: the classical, alternative, and lectin pathways; it is also activated by a recently identified fourth, extrinsic protease pathway (Huber-Lang et al., 2006, Thoman et al., 1984) (Figure 1).

The classical pathway is primarily activated in response to the recognition molecule $\mathrm{C} 1 \mathrm{q}$ binding to antigen-antibody complexes such as immunoglobins (IgG and $\operatorname{IgM}$ ) and pentraxins (such as C-reactive protein) bound to their targets (Ricklin et al., 2010, Woodruff et al., 2010). C1q may also bind directly to pathogen surfaces and to non-pathogen surfaces such as beta-amyloid and liposomes (Jiang et al., 1994, Marjan et al., 1994). The alternative pathway is activated by foreign surfaces which amplifies the slow spontaneous hydrolysis of C3 which leads to the formation of C3 convertases (Pangburn et al., 1981, Ricklin et al., 2010), whereas lectin pathway is initiated following the binding of mannose-binding lectin to carbohydrate groups on the surfaces of some pathogens (Woodruff et al., 2010). The activation of each of these pathways results in assembly of C3 and C5 convertase enzymes which cleave their respective inactive complement factors $\mathrm{C} 3$ and $\mathrm{C} 5$ into their active fragments $\mathrm{C} 3 \mathrm{a}, \mathrm{C} 3 \mathrm{~b}, \mathrm{C} 5 \mathrm{a}$ and $\mathrm{C} 5 \mathrm{~b}$. This leads to the formation of MAC through the nonenzymatic assembly of $\mathrm{C} 5 \mathrm{~b}$ with complement factors C6-C9, forming C5b-9 on the cell membrane, which creates a transmembrane pore, ultimately leading to cell lysis (Podack et al., 1982). A recently identified fourth extrinsic pathway involves direct cleavage of 
complement 3 (C3) and complement 5 (C5) into $\mathrm{C} 3 \mathrm{a} / \mathrm{C} 3 \mathrm{~b}$ and $\mathrm{C} 5 \mathrm{a} / \mathrm{C} 5 \mathrm{~b}$ by proteolytic enzymes (serine proteases) such as kallikrein, thrombin and cell-derived proteases (HuberLang et al., 2002, Huber-Lang et al., 2006). As a result, synthesis of C5 by local inflammatory cells can produce C5a via cleavage of C5 with cell derived proteases, even when devoid of the complement cascade precursor, C3 (Huber-Lang et al., 2006). This pathway may provide a source of complement activation factors in the absence of upstream complement activation, and in a local tissue environment such as the CNS (Woodruff et al., 2010).

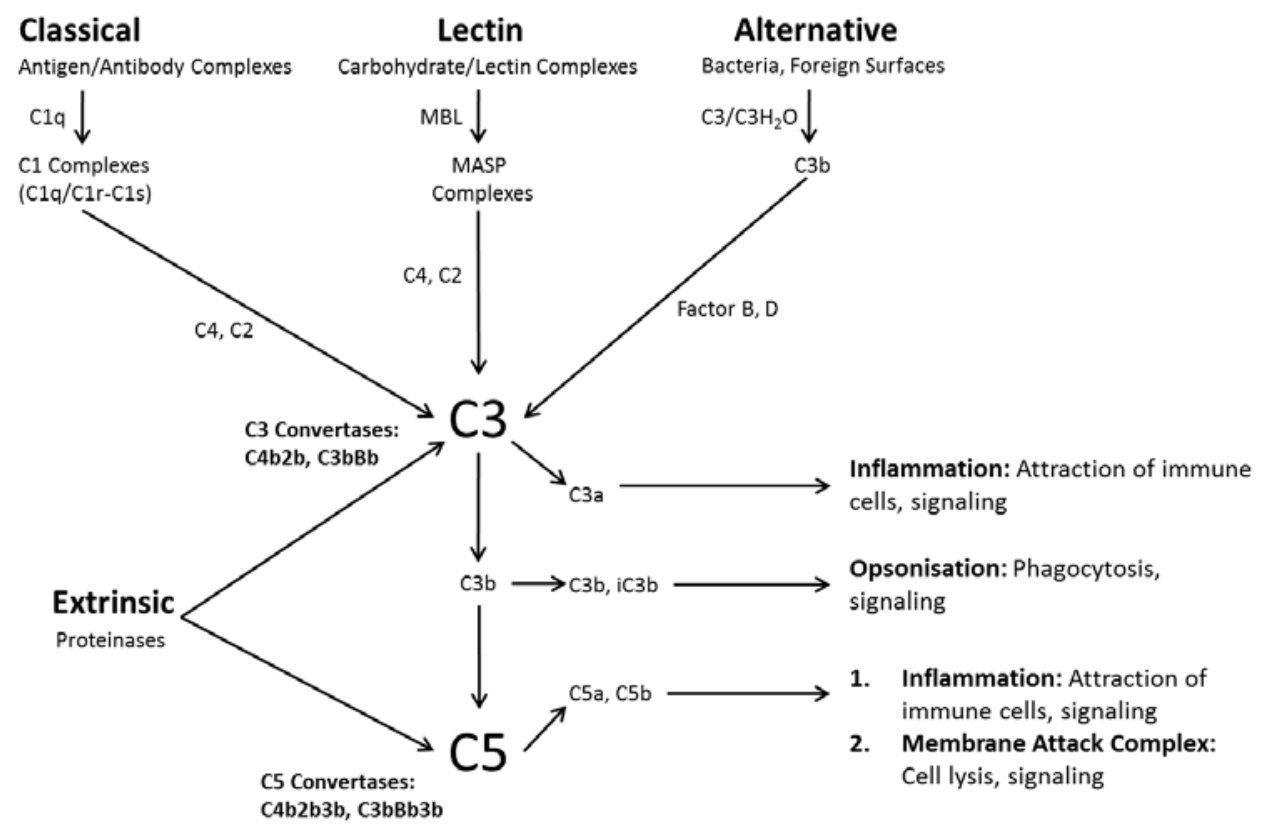

Fig. 1. Complement Cascade: Complement is part of the innate immune system and can be activated via four different pathways: the classical pathway, an antigen-antibody complex; the alternative pathway, activated by bacteria and foreign surfaces; the lectin pathway activated by mannose binding lectin; and recently discovered extrinsic protease pathway involving direct cleavage of C3 and C5. Each pathway converges at C3 and leads to a common terminal point which involves the formation of the cytolytic membrane attack complex (MAC) leading to cell lysis. Formation of pro-inflammatory anaphylatoxins C3a and C5a induces glial chemotaxis, generation of superoxide radicals and release of inflammatory mediators. $\mathrm{C} 3 \mathrm{~b}$ and $\mathrm{iC} 3 \mathrm{~b}$ facilitates phagocytosis by opsonising foreign pathogens.

The primary function of complement activation is to provide a rapid response to infection and injury by initiating the production of opsonins $\mathrm{C} 1 \mathrm{q}$ and $\mathrm{C} 3 \mathrm{~b}$ to opsonise pathogens, the production of the pro-inflammatory anaphylatoxins $\mathrm{C} 3 \mathrm{a}$ and $\mathrm{C} 5 \mathrm{a}$ to recruit immune and inflammatory cells through ligand-receptor interactions with their corresponding receptors, $\mathrm{C} 3 \mathrm{aR}$ and CD88, and the formation of cytolytic MAC, which ultimately leads to the destruction of invading organisms by cell apoptosis/necrosis (Liszewski et al., 1996). 
C5a is considered to be the most potent inflammatory molecule generated upon complement activation and exhibits a broad range of functions. C5a exerts its effect through two high affinity receptors, the classical C5aR (CD88), and the C5a-like receptor 2 (C5L2/GPR77). The main C5a receptor, CD88 is a member of the rhodopsin family of seven transmembrane domain receptors coupled to the hetero-metric $\mathrm{G}$ proteins of the Gi subtype: pertussis toxin-sensitive $G_{a i 2}, G_{a i 3}$ or pertussis toxin-insensitive $G_{a 16}$ (Amatruda et al., 1993, Johswich and Klos, 2007, Rollins et al., 1991). Cellular activation of CD88 involves intracellular calcium mobilization and activation of different signaling pathways including phosphatidylinositol-3-kinase/Akt (PI3Kץ; Perianayagam et al., 2002), Ras/B-Raf/mitogenactivated protein kinase (MAPK)/extracellular signal-related kinase (ERK) (Buhl et al., 1994), phospholipase $A_{2}$, phospholipase D (Cockcroft, 1992, Mullmann et al., 1990), protein kinase C (PKC; Buhl et al., 1994), p21-activated kinases, Rac GTPases (Huang et al., 1998), signal transducers and activators of transcription, sphingosine kinase (Melendez and Ibrahim, 2004) and NF-kB (Kastl et al., 2006). It is widely expressed on variety of cells and tissues, and its activation is known to have pro-inflammatory functions such as chemotaxis, degranulation, superoxide production, and release of proteases, eicosanoids, cytokines and chemokines from inflammatory cells (Gomez-Cambronero et al., 2007, Melendez and Ibrahim, 2004, Torres and Forman, 1999, Tsai et al., 2004).

The recently discovered C5a receptor, C5L2 has the conventional G-protein coupled receptor structure but it is not coupled to intracellular G-protein activated signaling pathways (Bamberg et al., 2010, Okinaga et al., 2003). Binding of C5a to C5L2 failed to induce intracellular calcium mobilization, extracellular signal-related kinase phosphorylation or receptor internalization, by contrast to CD88 (Cain and Monk, 2002, Okinaga et al., 2003). This has led to the proposal that C5L2 may act as a decoy anaphylatoxin receptor by regulating the availability of $\mathrm{C} 5$ a to $\mathrm{CD} 88$, or by forming oligomers with CD88 to interrupt C5a-CD88 signaling (Rabiet et al., 2007). Although the mechanisms underlying C5L2 activation are still unknown, several recent studies in C5L2 knockout mice have showed greater response to $\mathrm{C} 5 \mathrm{a}$, a greater influx of inflammatory cells and a greater release of IL-6 and TNF-a compared to the wild-type mice (Rabiet et al., 2007). This suggests that C5a signaling via C5L2 may exert anti- inflammatory functions which buffer the effects of the inflammatory C5a-CD88 signaling pathway (Rabiet et al., 2007). Furthermore, studies have shown that C5L2 may function as an intracellular receptor, which becomes activated only after ligand binds to CD88. It was suggested that C5L2 negatively modulates C5a-CD88 signaling and limits the signaling capacity of C5a via its interaction with CD88 and $\beta$ arrestins (Bamberg et al., 2010, Van Lith et al., 2009). Any role for C5L2 in neurodegenerative diseases has yet to be properly elucidated.

Although the CNS does not receive the same composition of circulating complement factors synthesised in the liver by hepatocytes, due to the blood brain barrier (BBB), many studies have revealed that the CNS contains components of complement cascade, where they are expressed by astrocytes, microglia, oligodendrocytes and neurons (Barnum, 1995, Gasque et al., 1997, Nataf et al., 2001, O'Barr et al., 2001). Similar to the peripheral system, the role of complement activation within the CNS is thought to primarily protect the neurons from foreign pathogens through activation of inflammatory and immune cascades by surrounding glial cells. In addition to their immune surveillance functions, recent studies have shown that complement molecules also have a role in adaptive immune response, nervous system development, regeneration and regulating CNS homeostasis by clearing 
cellular debris and also eliminating excess synapses (i.e. synaptic pruning) (Stevens et al., 2007). Intriguingly, synaptic loss is not only a feature of neural development but is also a key pathological feature of neurodegenerative diseases (Schafer and Stevens, 2010, Woodruff et al., 2010). Hence it has been proposed that complement has multiple central roles in the CNS other than its canonical functions associated with host defence (Benard et al., 2008, Rahpeymai et al., 2006, Stevens et al., 2007). Therefore dysregulation or imbalance of the complement system in the CNS can be harmful to the neurons and may lead to, or contribute to, neurodegenerative diseases including ALS.

\section{Clinical evidence of complement involvement in ALS}

Several studies have been conducted on ALS patients in an attempt to identify whether complement components are up-regulated in disease progression (Table 1). It has been proposed that the classical complement system is involved in the pathophysiology of ALS, as studies have shown that activation fragments of complement components C3 and C4 are increased in the serum, cerebrospinal fluid (CSF), and neurological tissue (including spinal cord and motor cortex) of ALS patients (Annunziata and Volpi, 1985, Apostolski et al., 1991, Goldknopf et al., 2006, Kawamata et al., 1992, Trbojevic-Cepe et al., 1998). The first of these studies examined C3 immunofluorescence in spinal cord and motor cortex of 16 ALS patients and demonstrated significant C3 deposition, which appeared to be on astrocyte-like cells with no apparent neuronal staining (Donnenfeld et al., 1984). Subsequent studies measured C3c, C4, C1 inactivator and C3 activator fractions in the serum and CSF of 13 ALS patients but only detected increased levels of C3c in the CSF of ALS patients compared to normal individuals (Annunziata and Volpi, 1985). Furthermore Apopstolski and colleagues (1991) measured serum C4, C3 and Factor B levels in 33 ALS patients and found an increase in C4 levels when compared to normal individuals. Increased clusters of C3d and C4d coated fibers on oligodendroglia and degenerating neurites in spinal cord and motor cortex was also found in 8 ALS patients compared to 5 normal individuals (Kawamata et al., 1992). Two separate studies also investigated C1q, C4d and C4 levels in the serum and CSF of ALS patients and found C4d levels significantly increased in 15 ALS patients which also correlated with disease severity (Tsuboi and Yamada, 1994); another study also detected upregulation of C4 in ALS patients (Trbojevic-Cepe et al., 1998). Studies by Grewal and colleagues (Grewal et al., 1999) and Jiang and colleagues (Jiang et al., 2005) have identified increased mRNA of upstream complement components (C1q and C2) in the spinal cord of ALS patients. Recently, Sta and colleagues have found increased levels of C1q, C3c, C3d and C5b-9 in the spinal cord and motor cortex of ALS patients compared to normal individuals (Sta et al., 2011). The expression of these complement components was observed in glial cells rather than neurons (Sta et al., 2011). Lastly, complement component C3 was also found to be upregulated in the CSF of 71 ALS patients when compared to 40 normal individuals (Ganesalingam et al., 2011).

These findings of upregulated complement components and activation fragments, predominantly composing the classical pathway, in the serum, CSF, and neurological tissue in ALS patients strongly suggest that the classical complement pathway is involved in the progression of disease in ALS. However it is currently unknown where these complement factors originate, and what initiates their activation. Complement factors can be produced by various cells of the CNS and thus these complement factors could be produced locally in response to disturbance in CNS homeostasis due to immunoglobulin deposits and auto- 
antibodies in the CNS of ALS patients (Donnenfeld et al., 1984, Niebroj-Dobosz et al., 2006). Also the circulation could be a source of these complement factors as there is BBB breakdown in the end stages of ALS (Apostolski et al., 1991). Overall, evidence from these clinical studies helps us to propose that complement system activation occurs in ALS patients, and may play a role in the disease pathology. This is also supported by evidence of studies showing involvement of complement factors in animal models of ALS.

\begin{tabular}{|c|c|c|c|}
\hline $\begin{array}{l}\text { Complement } \\
\text { factors }\end{array}$ & mRNA/Protein & Sample & Methods \\
\hline C3 & Protein & $\begin{array}{l}\text { Spinal Cord, } \\
\text { Motor cortex }\end{array}$ & Immunofluorescence \\
\hline $\mathrm{C} 3 \mathrm{c}$ & Protein & Serum, CSF & $\begin{array}{l}\text { Single radial immuno- } \\
\text { diffusion }\end{array}$ \\
\hline $\mathrm{C} 4$ & Protein & Serum & $\begin{array}{l}\text { Single radial immuno- } \\
\text { diffusion }\end{array}$ \\
\hline C3d, C4d & Protein & $\begin{array}{l}\text { Spinal Cord, } \\
\text { Motor cortex }\end{array}$ & Immunohistochemistry \\
\hline C4d & Protein & CSF & Sandwich ELISA \\
\hline $\mathrm{C} 4$ & Protein & CSF & Laser nephelometry \\
\hline $\mathrm{C} 1 \mathrm{q}$ & mRNA & $\begin{array}{l}\text { Spinal Cord, } \\
\text { Motor cortex }\end{array}$ & $\begin{array}{l}\text { Northern blot, In situ } \\
\text { hybridization }\end{array}$ \\
\hline $\mathrm{C} 2$ & mRNA & Spinal Cord & Microarray \\
\hline $\begin{array}{l}\mathrm{C} 3 \mathrm{c}, \mathrm{C} 3 \mathrm{dg} \\
\text { Factor } \mathrm{H}\end{array}$ & Protein & Serum & 2D gel electrophoresis \\
\hline $\begin{array}{l}\mathrm{C} 1 \mathrm{q}, \mathrm{C} 3 \mathrm{c}, \mathrm{C} 3 \mathrm{~d} \\
\mathrm{C} 5 \mathrm{~b}-9\end{array}$ & mRNA/Protein & $\begin{array}{l}\text { Spinal Cord, } \\
\text { Motor cortex }\end{array}$ & qPCR, immunohistochemistry \\
\hline C3 & Protein & CSF & Sandwich ELISA \\
\hline
\end{tabular}

Table 1. Clinical evidence of complement activation in ALS patients 


\section{Experimental evidence of complement involvement in ALS}

Many studies in animal models of ALS have shown the involvement of the complement system during disease progression, supporting findings in ALS patients (Table 2). Although the SOD1 gene mutation only accounts for $2 \%$ of total ALS cases, mouse models carrying over-expression of mutant SOD1 enzyme are widely used, as it leads to progressive symptoms which are very similar to the human condition.

\begin{tabular}{|c|c|c|c|}
\hline $\begin{array}{c}\text { Complement } \\
\text { factors }\end{array}$ & mRNA/Protein & Transgenic model & Reference \\
\hline C1q & mRNA & Mouse SOD1 G93A & (Perrin et al., 2005) \\
\hline C1q, DAF & mRNA & $\begin{array}{c}\text { Mouse SOD1 G37R and } \\
\text { SOD1 G85R }\end{array}$ & (Lobsiger et al., 2007) \\
\hline C1q, C4 & mRNA/Protein & Mouse SOD1 G93A & (Ferraiuolo et al., 2007) \\
\hline C1q & mRNA/Protein & Rat SOD1 G93A & (Woodruff et al., 2008a) \\
\hline CD88 & (Fukada et al., 2007) \\
\hline CD88 & mRNA/Protein & Mouse NFL - $/-$ & (Humayun et al., 2009) \\
\hline C1q, C3 & Mouse SOD1 G93A & (Heurich et al., 2011) \\
\hline
\end{tabular}

Table 2. Experimental evidence of complement activation in animal models of ALS

The first study to demonstrate experimentally the involvement of complement factors in a SOD1 transgenic mouse model was performed by Perrin and colleagues in 2005 . They isolated the ventral motor neurons from the lumbar spinal cord of SOD1G93A transgenic mouse using laser-capture micro-dissection and then using microarray analysis they detected increased levels of all subcomponents of $\mathrm{Clq}$ in these mice at early symptomatic and end stage when compared to motor neurons from wild-type mice $(\sim 5$ and $\sim 8$ fold respectively) (Perrin et al., 2005).

Subsequent studies in two distinct SOD1 transgenic mouse models also used laser-capture micro-dissection to isolate lumbar motor neurons from SOD1G37R and SOD1G85R transgenic mice which showed upregulation of genes for all three $\mathrm{C} 1 \mathrm{q}$ subcomponents when compared to SOD1WT mice 2 months prior to clinical onset (P105) (Lobsiger et al., 2007). In addition, this group demonstrated that the complement regulatory molecule, decay accelerating factor (DAF) also decreased at this time point (Lobsiger et al., 2007). Furthermore they showed that $\mathrm{Clq}$ protein was expressed by motor neurons using immunohistochemistry on spinal cord sections of both SOD1G37R and SOD1G85R transgenic mice but absent in the agematched control mice (Lobsiger et al., 2007). 
A separate group also used laser-capture microdissection to isolate the lumbar motor neurons from SOD1G93A transgenic mice. Using microarray analysis and real time quantitative PCR, they showed there were increased levels of $\mathrm{C} 1 \mathrm{q}$ (subcomponent $\mathrm{B}$ ) and C4 mRNA at disease onset (P90) and late-stage disease (P120) ( $\sim 7$ and $\sim 8$ fold respectively) (Ferraiuolo et al., 2007). A similar study also used microarray analysis in a separate SOD1 transgenic mouse model using whole lumbar spinal cord homogenate (Fukada et al., 2007). This study used SOD1L126delTT transgenic mice and showed elevated levels of C1q (subcomponent B) mRNA in post-symptomatic (P154) mice compared to wild-type mice. A very recent study has shown increased levels of $\mathrm{C} 1 \mathrm{q}$ in the neuromuscular junction of SOD1G93A transgenic mice compared to wild-type mice (Heurich et al., 2011).

By contrast to the above studies, which indicates a role for the classical complement pathway in the progression of pathology of the SOD1 transgenic mouse, a recent study has demonstrated that when SOD1G93A transgenic mice were bred onto a background deficient in complement C4 (a necessary component of the classical complement pathway, downstream of $\mathrm{Clq}$ ), there was a difference in the macrophage levels and activation in the peripheral nervous system but no difference in the onset of motor symptoms and survival when compared to wild-type mice (Chiu et al., 2009). This study indicates that other molecular pathways such as the alternative or extrinsic pathway may play compensatory roles in immune activation and macrophage recruitment in the absence of the classical pathway in these mice. To support this, recent studies in SOD1G93A transgenic mouse showed increases in the $\mathrm{C} 3 \mathrm{mRNA}$ and protein levels in the spinal cord when compared to wild-type animals at symptomatic stage (P126) (Heurich et al., 2011). They also observed upregulation of $\mathrm{C} 3$ at the motor end plate and nerve terminals in the SOD1G93A transgenic mice at pre-symptomatic stage (P47) when compared to wild-type animal (Heurich et al., 2011).

To further validate the involvement of downstream components of the complement cascade in the disease progression of ALS, upregulation of C5a receptor CD88 mRNA and protein was observed in mice deficient in the low molecular weight neurofilament (NFL) subunit protein, a mouse model of motor neuron degeneration in which neurofilament aggregates in a similar fashion to that in ALS patients (Humayun et al., 2009). This study showed there was a 4 and 3 fold increase in CD88 mRNA expression level at 2 and 3 months respectively, a time which is early in the disease process (Humayun et al., 2009). There was also an increased immunoreactivity of CD88 in motor neurons of NFL deficient mice when compared to wild-type mice at 3,4 and 5 months. Our own findings also support a pathogenic role for C5a in ALS (Woodruff et al., 2008a). Chronic administration of a specific C5a receptor antagonist, developed in our laboratories (Wong et al., 1998) in SOD1G93A transgenic rats, markedly delayed the onset of motor symptoms and increased survival, compared to untreated animals (Woodruff et al., 2008a). We also showed upregulation of CD88 in the lumbar spinal cord of SOD1G93A transgenic rats, which increased as disease progressed (Woodruff et al., 2008a).

These findings of upregulated complement components in different animal models of ALS suggest that the activation of complement system is critically linked with disease progression in ALS. Whilst inhibition of one component of the classical and lectin complement pathway, C4, failed to ameliorate disease in SOD1G93A transgenic mice, inhibition of the classical receptor for C5a, CD88, reduced disease pathology in SOD1G93A transgenic rats. It should be noted that $\mathrm{C} 5 \mathrm{a}$ is expressed following activation of all 
complement pathways (Figure 1). Hence inhibiting central components of the complement system, at the C3 and C5 level, may have benefits in slowing disease progression in ALS, as opposed to inhibiting an individual activation pathway. Specifically, our studies suggest that inhibiting the pro-inflammatory $\mathrm{C} 5$ activation fragment, $\mathrm{C} 5 \mathrm{a}$, which is central to, and generated by, all complement pathways, may be a novel therapeutic strategy to treat ALS.

\section{Future directions: Therapeutic applications}

To date, riluzole (Rilutek, Aventis Pharmaceuticals Inc) is the only approved therapeutic to treat ALS; it is known to prevent the pre-synaptic release of glutamine (Bellingham, 2011, Miller et al., 2007). In clinical trials, it has been shown to extend survival by around $2 \sim 3$ months and delay the onset of ventilator dependence or tracheostomy (Bellingham, 2011, Miller et al., 2007). It is not clear that the drug improves the quality of life, however. Given this modest extension of $\sim 2-3$ months in survival there is an urgent need to develop new therapeutics which will significantly extend survival and also decrease morbidity in ALS.

Recent studies have suggested that the innate immune system is important in sensing ALS progression and its subsequent upregulation may drive the progression of this disease (Woodruff et al., 2008b). The complement system would be a logical and viable pathway to target, given the steadily accumulating clinical evidence of complement involvement in this disease. This is also supported by our findings where using specific C5a receptor antagonist improved motor symptoms and extended survival in the SOD1G93A transgenic rat (Woodruff et al., 2008a).

Our laboratories have developed a series of cyclic peptide C5a receptor antagonists which are potent inhibitors of C5a receptors on human inflammatory cells (Woodruff et al., 2011). PMX53 (AcF-[OPdChaWR] and PMX205 (hydrocinnamate-[OPdChaWR]) are orally active cyclic hexapeptides, which were derived from the linear CD88 antagonist, Me-FKPdChaWR (Konteatis et al., 1994) that were cyclised to induce structural and metabolic stability(Finch et al., 1999, March et al., 2004). These drugs have been shown to display therapeutic efficacy in numerous rodent models of inflammatory disease including rheumatoid arthritis (Woodruff et al., 2002), ischemic reperfusion injuries (Arumugam et al., 2004) and inflammatory bowel disease (Woodruff et al., 2003), as well as acute neurodegeneration (Woodruff et al., 2006). PMX205 is more lipophilic than the original CD88 antagonist PMX53, which results in increased potency in certain inflammatory models (Woodruff et al., 2005) and increased CNS penetrance (Woodruff et al., 2006). Hence, it has been used to reduce disease severity and prolong survival in animal models of neural degeneration including Huntington's disease, Alzheimer's disease and ALS (Ager et al., 2010, Fonseca et al., 2009, Woodruff et al., 2006, Woodruff et al., 2008a). As a result of this work, PMX205 would be the particular PMX series compound we would promote for any future clinical trialling in ALS.

In addition to inhibiting C5a receptors, targeting other factors of the complement system may provide viable therapeutic options to treat ALS. Several complement inhibitors have been developed over the years and compounds such as sCR1, C5 antibodies, compstatin or others could be used as potential therapies for ALS. However, due to the need to chronically administer a drug in ALS, a small, orally active and BBB permeable complement inhibitor, such as PMX205, would be required. The selectivity of PMX205 towards the classical C5a receptor leaves other components of the complement system intact, allowing for the production of complement factors including the MAC, thus reducing immune suppression - 
a likely side effect of other inhibitors of complement which act more upstream in the system, were they are to be used chronically. Finally, PMX53, an analogue to PMX205 has already been shown to be safe when administered to humans, successfully completing three Phase I/IIa clinical trials, thus promoting the safety of these classes of drugs in humans (Woodruff et al., 2011).

In addition to anti-complement agents, combined therapies targeting multiple and disparate pathways will most likely be needed to effectively treat ALS. Extensive controlled clinical trials will need to be conducted in order to ascertain any potential therapeutic benefit of a complement inhibitor to treat the devastating and intractable nature of ALS.

\section{Conclusion}

There is increasing evidence that implicates the involvement of the innate immune system in the progression of ALS. In particular, the inappropriate activation or dysregulation of the complement system may play a role in ALS pathology. Evidence for this includes elevated levels of complement activation fragments in the serum, CSF, spinal cord and motor cortex of ALS patients. This has also been supported with elevated levels of complement activation fragments in various animal models of ALS. Moreover, inhibition of the C5a receptor using a specific C5a receptor antagonist ameliorated disease symptoms in a rat model of ALS. Collectively, these studies suggest that complement activation may play a crucial role in the progression of ALS. Hence reducing complement-induced inflammation using inhibitors to target complement factors could be an important therapeutic strategy to treat ALS.

\section{Acknowledgments}

We acknowledge the funding support of the Motor Neuron Disease Research Institute of Australia (Charles \& Shirley Graham MND Research Grant 2010), and the National Health and Medical Research Council of Australia (Project Grants 455856 and APP1004455).

\section{References}

Ager, R. R., Fonseca, M. I., Chu, S. H., Sanderson, S. D., Taylor, S. M., Woodruff, T. M. \& Tenner, A. J. (2010). Microglial C5aR (CD88) expression correlates with amyloidbeta deposition in murine models of Alzheimer's disease. J Neurochem, Vol.113, No.2, (April 2010), pp.389-401, ISSN 1471-4159.

Akira, S., Takeda, K. \& Kaisho, T. (2001). Toll-like receptors: critical proteins linking innate and acquired immunity. Nature immunology, Vol.2, No.8, (August 2001), pp.675680, ISSN 1529-2908.

Amatruda, T. T., 3RD, Gerard, N. P., Gerard, C. \& Simon, M. I. (1993). Specific interactions of chemoattractant factor receptors with G-proteins. The Journal of biological chemistry, Vol.268, No.14, (May 1993), pp.10139-10144, ISSN 0021-9258.

Andersson, A., Covacu, R., Sunnemark, D., Danilov, A. I., Dal Bianco, A., Khademi, M., Wallstrom, E., Lobell, A., Brundin, L., Lassmann, H. \& Harris, R. A. (2008). Pivotal advance: HMGB1 expression in active lesions of human and experimental multiple sclerosis. Journal of leukocyte biology, Vol.84, No.5, (November 2008), pp.1248-1255, ISSN 0741-5400. 
Annunziata, P. \& Volpi, N. (1985). High levels of C3c in the cerebrospinal fluid from amyotrophic lateral sclerosis patients. Acta neurologica Scandinavica, Vol.72, No.1, (July 1985), pp.61-64, ISSN 0001-6314.

Apostolski, S., Nikolic, J., Bugarski-Prokopljevic, C., Miletic, V., Pavlovic, S. \& Filipovic, S. (1991). Serum and CSF immunological findings in ALS. Acta neurologica Scandinavica, Vol.83, No.2, (February 1991), pp.96-98, ISSN 0001-6314.

Aravalli, R. N., Peterson, P. K. \& Lokensgard, J. R. (2007). Toll-like receptors in defense and damage of the central nervous system. Journal of neuroimmune pharmacology : the official journal of the Society on NeuroImmune Pharmacology, Vol.2, No.4, (December 2007), pp.297-312, ISSN 1557-1904.

Arumugam, T. V., Shiels, I. A., Woodruff, T. M., Granger, D. N. \& Taylor, S. M. (2004). The role of the complement system in ischemia-reperfusion injury. Shock, Vol.21, No.5, (May 2004), pp.401-409, ISSN 1073-2322.

Bamberg, C. E., Mackay, C. R., Lee, H., Zahra, D., Jackson, J., Lim, Y. S., Whitfeld, P. L., Craig, S., Corsini, E., Lu, B., Gerard, C. \& Gerard, N. P. (2010). The C5a receptor $(\mathrm{C} 5 \mathrm{aR}) \mathrm{C} 5 \mathrm{~L} 2$ is a modulator of $\mathrm{C} 5 \mathrm{aR}$-mediated signal transduction. Journal of Biological Chemistry, Vol.285, No.10, (March 2010), pp.7633-7644, ISSN 1083-351X.

Barnum, S. R. (1995). Complement biosynthesis in the central nervous system. Crit Rev Oral Biol Med, Vol.6, No.2, (January 1995), pp.132-146, ISSN 1045-4411.

Bellingham, M. C. (2011). A review of the neural mechanisms of action and clinical efficiency of riluzole in treating amyotrophic lateral sclerosis: what have we learned in the last decade? CNS neuroscience E therapeutics, Vol.17, No.1, (February 2011), pp.4-31, ISSN 1755-5949.

Benard, M., Raoult, E., Vaudry, D., Leprince, J., Falluel-Morel, A., Gonzalez, B. J., Galas, L., Vaudry, H. \& Fontaine, M. (2008). Role of complement anaphylatoxin receptors $(\mathrm{C} 3 \mathrm{aR}, \mathrm{C} 5 \mathrm{aR})$ in the development of the rat cerebellum. Molecular immunology, Vol.45, No.14, (August 2008), pp.3767-3774, ISSN 0161-5890.

Bianchi, M. E. \& Manfredi, A. A. (2007). High-mobility group box 1 (HMGB1) protein at the crossroads between innate and adaptive immunity. Immunological reviews, Vol.220, (December 2007), pp.35-46, ISSN 0105-2896.

Bianchi, M. E. \& Manfredi, A. A. (2009). Immunology. Dangers in and out. Science, Vol.323, No.5922, (March 2009), pp.1683-1684, ISSN 1095-9203.

Boillee, S., Vande Velde, C. \& Cleveland, D. W. (2006). ALS: a disease of motor neurons and their nonneuronal neighbors. Neuron, Vol.52, No.1, (October 2006), pp.39-59, ISSN 0896-6273.

Bowman, C. C., Rasley, A., Tranguch, S. L. \& Marriott, I. (2003). Cultured astrocytes express toll-like receptors for bacterial products. Glia, Vol.43, No.3, (September 2003), pp.281-291, ISSN 0894-1491.

Bruijn, L. I. \& Cleveland, D. W. (1996). Mechanisms of selective motor neuron death in ALS: insights from transgenic mouse models of motor neuron disease. Neuropathol Appl Neurobiol, Vol.22, No.5, (October 1996), pp.373-387, ISSN 0305-1846.

Bruijn, L. I., Miller, T. M. \& Cleveland, D. W. (2004). Unraveling the mechanisms involved in motor neuron degeneration in ALS. Annu Rev Neurosci, Vol.27, (June 2004), pp.723749, ISSN 0147-006X. 
Buhl, A. M., Avdi, N., Worthen, G. S. \& Johnson, G. L. (1994). Mapping of the C5a receptor signal transduction network in human neutrophils. Proc Natl Acad Sci U S A, Vol.91, No.19, (September 1994), pp.9190-9194, ISSN 0027-8424.

Cain, S. A. \& Monk, P. N. (2002). The orphan receptor C5L2 has high affinity binding sites for complement fragments C5a and C5a des-Arg(74). Journal of Biological Chemistry, Vol.277, No.9, (March 2002), pp.7165-7169, ISSN 0021-9258.

Casula, M., Iyer, A. M., Spliet, W. G., Anink, J. J., Steentjes, K., Sta, M., Troost, D. \& Aronica, E. (2011). Toll-like receptor signaling in amyotrophic lateral sclerosis spinal cord tissue. Neuroscience, Vol.179, (April 2011), pp.233-243, ISSN 1873-7544.

Chiu, I. M., Phatnani, H., Kuligowski, M., Tapia, J. C., Carrasco, M. A., Zhang, M., Maniatis, T. \& Carroll, M. C. (2009). Activation of innate and humoral immunity in the peripheral nervous system of ALS transgenic mice. Proceedings of the National Academy of Sciences of the United States of America, Vol.106, No.49, (December 2009), pp.20960-20965, ISSN 1091-6490.

Cockcroft, S. (1992). G-protein-regulated phospholipases C, D and A2-mediated signalling in neutrophils. Biochim Biophys Acta, Vol.1113, No.2, (August 1992), pp.135-160, ISSN 0006-3002.

Cozzolino, M., Ferri, A. \& Carri, M. T. (2008). Amyotrophic lateral sclerosis: from current developments in the laboratory to clinical implications. Antioxid Redox Signal, Vol.10, No.3, (March 2008), pp.405-443, ISSN 1523-0864.

Donnenfeld, H., Kascsak, R. J. \& Bartfeld, H. (1984). Deposits of IgG and C3 in the spinal cord and motor cortex of ALS patients. Journal of neuroimmunology, Vol.6, No.1, (February 1984), pp.51-57, ISSN 0165-5728.

Ferraiuolo, L., Heath, P. R., Holden, H., Kasher, P., Kirby, J. \& Shaw, P. J. (2007). Microarray analysis of the cellular pathways involved in the adaptation to and progression of motor neuron injury in the SOD1 G93A mouse model of familial ALS. The Journal of neuroscience : the official journal of the Society for Neuroscience, Vol.27, No.34, (August 2007), pp.9201-9219, ISSN 1529-2401.

Finch, A. M., Wong, A. K., Paczkowski, N. J., Wadi, S. K., Craik, D. J., Fairlie, D. P. \& Taylor, S. M. (1999). Low-molecular-weight peptidic and cyclic antagonists of the receptor for the complement factor C5a. Journal of medicinal chemistry, Vol.42, No.11, (June 1999), pp.1965-1974, ISSN 0022-2623.

Fonseca, M. I., Ager, R. R., Chu, S. H., Yazan, O., Sanderson, S. D., Laferla, F. M., Taylor, S. M., Woodruff, T. M. \& Tenner, A. J. (2009). Treatment with a C5aR antagonist decreases pathology and enhances behavioral performance in murine models of Alzheimer's disease. J Immunol, Vol.183, No.2, (July 2009), pp.1375-1383, ISSN 15506606.

Fukada, Y., Yasui, K., Kitayama, M., Doi, K., Nakano, T., Watanabe, Y. \& Nakashima, K. (2007). Gene expression analysis of the murine model of amyotrophic lateral sclerosis: studies of the Leu126delTT mutation in SOD1. Brain research, Vol.1160, (July 2007), pp.1-10, ISSN 0006-8993.

Ganesalingam, J., An, J., Shaw, C. E., Shaw, G., Lacomis, D. \& Bowser, R. (2011). Combination of neurofilament heavy chain and complement C3 as CSF biomarkers for ALS. Journal of neurochemistry, Vol.117, No.3, (May 2011), pp.528-537, ISSN 1471-4159. 
Gasque, P., Singhrao, S. K., Neal, J. W., Gotze, O. \& Morgan, B. P. (1997). Expression of the receptor for complement $\mathrm{C} 5 \mathrm{a}(\mathrm{CD} 88)$ is up-regulated on reactive astrocytes, microglia, and endothelial cells in the inflamed human central nervous system. Am J Pathol, Vol.150, No.1, (January 1997), pp.31-41, ISSN 0002-9440.

Goldknopf, I. L., Sheta, E. A., Bryson, J., Folsom, B., Wilson, C., Duty, J., Yen, A. A. \& Appel, S. H. (2006). Complement $\mathrm{C} 3 \mathrm{c}$ and related protein biomarkers in amyotrophic lateral sclerosis and Parkinson's disease. Biochem Biophys Res Commun, Vol.342, No.4, (April 2006), pp.1034-1039, ISSN 0006-291X.

Gomez-Cambronero, J., Di Fulvio, M. \& Knapek, K. (2007). Understanding phospholipase D (PLD) using leukocytes: PLD involvement in cell adhesion and chemotaxis. J Leukoc Biol, Vol.82, No.2, (August 2007), pp.272-281, ISSN 0741-5400.

Grewal, R. P., Morgan, T. E. \& Finch, C. E. (1999). C1qB and clusterin mRNA increase in association with neurodegeneration in sporadic amyotrophic lateral sclerosis. Neurosci Lett, Vol.271, No.1, (August 1999), pp.65-67, ISSN 0304-3940.

Guo, R. F. \& Ward, P. A. (2005). Role of C5a in inflammatory responses. Annu Rev Immunol, Vol.23, (March 2005), pp.821-852, ISSN 0732-0582.

Hanisch, U. K., Johnson, T. V. \& Kipnis, J. (2008). Toll-like receptors: roles in neuroprotection? Trends in neurosciences, Vol.31, No.4, (April 2008), pp.176-182, ISSN 0166-2236.

Heurich, B., El Idrissi, N. B., Donev, R. M., Petri, S., Claus, P., Neal, J., Morgan, B. P. \& Ramaglia, V. (2011). Complement upregulation and activation on motor neurons and neuromuscular junction in the SOD1 G93A mouse model of familial amyotrophic lateral sclerosis. Journal of neuroimmunology, Vol.235, No.1-2, (June 2011), pp.104-109, ISSN 1872-8421.

Hreggvidsdottir, H. S., Ostberg, T., Wahamaa, H., Schierbeck, H., Aveberger, A. C., Klevenvall, L., Palmblad, K., Ottosson, L., Andersson, U. \& Harris, H. E. (2009). The alarmin HMGB1 acts in synergy with endogenous and exogenous danger signals to promote inflammation. Journal of leukocyte biology, Vol.86, No.3, (September 2009), pp.655-662, ISSN 1938-3673.

Huang, R., Lian, J. P., Robinson, D. \& Badwey, J. A. (1998). Neutrophils stimulated with a variety of chemoattractants exhibit rapid activation of p21-activated kinases (Paks): separate signals are required for activation and inactivation of paks. Mol Cell Biol, Vol.18, No.12, (December 1998), pp.7130-7138, ISSN 0270-7306.

Huber-Lang, M., Sarma, J. V., Zetoune, F. S., Rittirsch, D., Neff, T. A., Mcguire, S. R., Lambris, J. D., Warner, R. L., Flierl, M. A., Hoesel, L. M., Gebhard, F., Younger, J. G., Drouin, S. M., Wetsel, R. A. \& Ward, P. A. (2006). Generation of C5a in the absence of C3: a new complement activation pathway. Nat Med, Vol.12, No.6, (June 2006), pp.682-687, ISSN 1078-8956.

Huber-Lang, M., Younkin, E. M., Sarma, J. V., Riedemann, N., Mcguire, S. R., Lu, K. T., Kunkel, R., Younger, J. G., Zetoune, F. S. \& Ward, P. A. (2002). Generation of C5a by phagocytic cells. Am J Pathol, Vol.161, No.5, (November 2002), pp.1849-1859, ISSN 0002-9440.

Humayun, S., Gohar, M., Volkening, K., Moisse, K., Leystra-Lantz, C., Mepham, J., Mclean, J. \& Strong, M. J. (2009). The complement factor C5a receptor is upregulated in 
NFL-/- mouse motor neurons. J Neuroimmunol, Vol.210, No.1-2, (May 2009), pp.5262, ISSN 1872-8421.

Ilzecka, J. (2009). Serum-soluble receptor for advanced glycation end product levels in patients with amyotrophic lateral sclerosis. Acta neurologica Scandinavica, Vol.120, No.2, (August 2009), pp.119-122, ISSN 1600-0404.

Jiang, H., Burdick, D., Glabe, C. G., Cotman, C. W. \& Tenner, A. J. (1994). beta-Amyloid activates complement by binding to a specific region of the collagen-like domain of the C1q A chain. Journal of immunology, Vol.152, No.10, (May 1994), pp.5050-5059, ISSN 0022-1767.

Jiang, Y. M., Yamamoto, M., Kobayashi, Y., Yoshihara, T., Liang, Y., Terao, S., Takeuchi, H., Ishigaki, S., Katsuno, M., Adachi, H., Niwa, J., Tanaka, F., Doyu, M., Yoshida, M., Hashizume, Y. \& Sobue, G. (2005). Gene expression profile of spinal motor neurons in sporadic amyotrophic lateral sclerosis. Ann Neurol, Vol.57, No.2, (February 2005), pp.236-251, ISSN 0364-5134.

Johswich, K. \& Klos, A. (2007). C5L2--an anti-inflammatory molecule or a receptor for acylation stimulating protein (C3a-desArg)? Advances in experimental medicine and biology, Vol.598, (September 2007), pp.159-180, ISSN 0065-2598.

Kastl, S. P., Speidl, W. S., Kaun, C., Rega, G., Assadian, A., Weiss, T. W., Valent, P., Hagmueller, G. W., Maurer, G., Huber, K. \& Wojta, J. (2006). The complement component $\mathrm{C} 5 \mathrm{a}$ induces the expression of plasminogen activator inhibitor- 1 in human macrophages via NF-kappaB activation. J Thromb Haemost, Vol.4, No.8, (August 2006), pp.1790-1797, ISSN 1538-7933.

Kawamata, T., Akiyama, H., Yamada, T. \& Mcgeer, P. L. (1992). Immunologic reactions in amyotrophic lateral sclerosis brain and spinal cord tissue. The American journal of pathology, Vol.140, No.3, (March 1992), pp.691-707, ISSN 0002-9440.

Konteatis, Z. D., Siciliano, S. J., Van Riper, G., Molineaux, C. J., Pandya, S., Fischer, P., Rosen, H., Mumford, R. A. \& Springer, M. S. (1994). Development of C5a receptor antagonists. Differential loss of functional responses. Journal of immunology, Vol.153, No.9, (November 1994), pp.4200-4205, ISSN 0022-1767.

Lehnardt, S. (2010). Innate immunity and neuroinflammation in the CNS: the role of microglia in Toll-like receptor-mediated neuronal injury. Glia, Vol.58, No.3, (February 2010), pp.253-263, ISSN 1098-1136.

Letiembre, M., Liu, Y., Walter, S., Hao, W., Pfander, T., Wrede, A., Schulz-Schaeffer, W. \& Fassbender, K. (2009). Screening of innate immune receptors in neurodegenerative diseases: a similar pattern. Neurobiology of aging, Vol.30, No.5, (May 2009), pp.759768, ISSN 1558-1497.

Liew, F. Y., Xu, D., Brint, E. K. \& O'neill, L. A. (2005). Negative regulation of toll-like receptor-mediated immune responses. Nature reviews. Immunology, Vol.5, No.6, (June 2005), pp.446-458, ISSN 1474-1733.

Liszewski, M. K., Farries, T. C., Lublin, D. M., Rooney, I. A. \& Atkinson, J. P. (1996). Control of the complement system. Advances in immunology, Vol.61, (January 1996), pp.201283, ISSN 0065-2776.

Liu, Y., Hao, W., Dawson, A., Liu, S. \& Fassbender, K. (2009). Expression of amyotrophic lateral sclerosis-linked SOD1 mutant increases the neurotoxic potential of microglia 
via TLR2. The Journal of biological chemistry, Vol.284, No.6, (February 2009), pp.36913699, ISSN 0021-9258.

Lobsiger, C. S., Boillee, S. \& Cleveland, D. W. (2007). Toxicity from different SOD1 mutants dysregulates the complement system and the neuronal regenerative response in ALS motor neurons. Proc Natl Acad Sci U S A, Vol.104, No.18, (May 2007), pp.73197326, ISSN 0027-8424.

March, D. R., Proctor, L. M., Stoermer, M. J., Sbaglia, R., Abbenante, G., Reid, R. C., Woodruff, T. M., Wadi, K., Paczkowski, N., Tyndall, J. D., Taylor, S. M. \& Fairlie, D. P. (2004). Potent cyclic antagonists of the complement C5a receptor on human polymorphonuclear leukocytes. Relationships between structures and activity. Mol Pharmacol, Vol.65, No.4, (April 2004), pp.868-879, ISSN 0026-895X.

Marjan, J., Xie, Z. \& Devine, D. V. (1994). Liposome-induced activation of the classical complement pathway does not require immunoglobulin. Biochimica et biophysica acta, Vol.1192, No.1, (June 1994), pp.35-44, ISSN 0006-3002.

Mastellos, D., Germenis, A. E. \& Lambris, J. D. (2005). Complement: an inflammatory pathway fulfilling multiple roles at the interface of innate immunity and development. Current drug targets. Inflammation and allergy, Vol.4, No.1, (February 2005), pp.125-127, ISSN 1568-010X.

Melendez, A. J. \& Ibrahim, F. B. (2004). Antisense knockdown of sphingosine kinase 1 in human macrophages inhibits $\mathrm{C} 5$ a receptor-dependent signal transduction, $\mathrm{Ca} 2+$ signals, enzyme release, cytokine production, and chemotaxis. J Immunol, Vol.173, No.3, (August 2004), pp.1596-1603, ISSN 0022-1767.

Miller, R. G., Mitchell, J. D., Lyon, M. \& Moore, D. H. (2007). Riluzole for amyotrophic lateral sclerosis (ALS)/motor neuron disease (MND). Cochrane Database Syst Rev, No.1, (January 2007), pp.CD001447, ISSN 1469-493X.

Mouri, F., Tsukada, J., Mizobe, T., Higashi, T., Yoshida, Y., Minami, Y., Izumi, H., Kominato, Y., Kohno, K. \& Tanaka, Y. (2008). Intracellular HMGB1 transactivates the human IL1B gene promoter through association with an Ets transcription factor PU.1. European journal of haematology, Vol.80, No.1, (January 2008), pp.10-19, ISSN 16000609.

Mullmann, T. J., Siegel, M. I., Egan, R. W. \& Billah, M. M. (1990). Complement C5a activation of phospholipase $\mathrm{D}$ in human neutrophils. A major route to the production of phosphatidates and diglycerides. J Immunol, Vol.144, No.5, (March 1990), pp.1901-1908, ISSN 0022-1767.

Nataf, S., Levison, S. W. \& Barnum, S. R. (2001). Expression of the anaphylatoxin C5a receptor in the oligodendrocyte lineage. Brain Res, Vol.894, No.2, (March 2001), pp.321-326, ISSN 0006-8993.

Nguyen, M. D., D'aigle, T., Gowing, G., Julien, J. P. \& Rivest, S. (2004). Exacerbation of motor neuron disease by chronic stimulation of innate immunity in a mouse model of amyotrophic lateral sclerosis. The Journal of neuroscience : the official journal of the Society for Neuroscience, Vol.24, No.6, (February 2004), pp.1340-1349, ISSN 15292401.

Niebroj-Dobosz, I., Dziewulska, D. \& Janik, P. (2006). Auto-antibodies against proteins of spinal cord cells in cerebrospinal fluid of patients with amyotrophic lateral sclerosis (ALS). Folia neuropathologica / Association of Polish Neuropathologists and Medical 
Research Centre, Polish Academy of Sciences, Vol.44, No.3, (October 2006), pp.191-196, ISSN 1641-4640.

O'barr, S. A., Caguioa, J., Gruol, D., Perkins, G., Ember, J. A., Hugli, T. \& Cooper, N. R. (2001). Neuronal expression of a functional receptor for the C5a complement activation fragment. J Immunol, Vol.166, No.6, (March 2001), pp.4154-4162, ISSN 0022-1767.

Okinaga, S., Slattery, D., Humbles, A., Zsengeller, Z., Morteau, O., Kinrade, M. B., Brodbeck, R. M., Krause, J. E., Choe, H. R., Gerard, N. P. \& Gerard, C. (2003). C5L2, a nonsignaling C5A binding protein. Biochemistry, Vol.42, No.31, (August 2003), pp.9406-9415, ISSN 0006-2960.

Olson, J. K. \& Miller, S. D. (2004). Microglia initiate central nervous system innate and adaptive immune responses through multiple TLRs. Journal of immunology, Vol.173, No.6, (September 2004), pp.3916-3924, ISSN 0022-1767.

Pangburn, M. K., Schreiber, R. D. \& Muller-Eberhard, H. J. (1981). Formation of the initial C3 convertase of the alternative complement pathway. Acquisition of C3b-like activities by spontaneous hydrolysis of the putative thioester in native C3. The Journal of experimental medicine, Vol.154, No.3, (September 1981), pp.856-867, ISSN 0022-1007.

Parker, L. C., Whyte, M. K., Vogel, S. N., Dower, S. K. \& Sabroe, I. (2004). Toll-like receptor (TLR)2 and TLR4 agonists regulate CCR expression in human monocytic cells. Journal of immunology, Vol.172, No.8, (April 2004), pp.4977-4986, ISSN 0022-1767.

Perianayagam, M.C., Balakrishnan, V.S., King, A.J., Pereira, B.J., Jaber, B.L., (2002). C5a delays apoptosis of human neutrophils by a phosphatidylinositol 3-kinase signaling pathway. Kidney Int, Vol.61, No.2, (February 2002), pp.456-463, ISSN 0085-2538.

Perrin, F. E., Boisset, G., Docquier, M., Schaad, O., Descombes, P. \& Kato, A. C. (2005). No widespread induction of cell death genes occurs in pure motoneurons in an amyotrophic lateral sclerosis mouse model. Human molecular genetics, Vol.14, No.21, (November 2005), pp.3309-3320, ISSN 0964-6906.

Podack, E. R., Tschoop, J. \& Muller-Eberhard, H. J. (1982). Molecular organization of C9 within the membrane attack complex of complement. Induction of circular C9 polymerization by the C5b-8 assembly. The Journal of experimental medicine, Vol.156, No.1, (July 1982), pp.268-282, ISSN 0022-1007.

Rabiet, M. J., Huet, E. \& Boulay, F. (2007). The N-formyl peptide receptors and the anaphylatoxin C5a receptors: an overview. Biochimie, Vol.89, No.9, (Septmeber 2007), pp.1089-1106, ISSN 0300-9084.

Rahpeymai, Y., Hietala, M. A., Wilhelmsson, U., Fotheringham, A., Davies, I., Nilsson, A. K., Zwirner, J., Wetsel, R. A., Gerard, C., Pekny, M. \& Pekna, M. (2006). Complement: a novel factor in basal and ischemia-induced neurogenesis. The EMBO journal, Vol.25, No.6, (March 2006), pp.1364-1374, ISSN 0261-4189.

Ricklin, D., Hajishengallis, G., Yang, K. \& Lambris, J. D. (2010). Complement: a key system for immune surveillance and homeostasis. Nature immunology, Vol.11, No.9, (September 2010), pp.785-797, ISSN 1529-2916.

Rollins, T. E., Siciliano, S., Kobayashi, S., Cianciarulo, D. N., Bonilla-Argudo, V., Collier, K. \& Springer, M. S. (1991). Purification of the active C5a receptor from human 
polymorphonuclear leukocytes as a receptor-Gi complex. Proceedings of the National Academy of Sciences of the United States of America, Vol.88, No.3, (February 1991), pp.971-975, ISSN 0027-8424.

Rosen, D. R., Siddique, T., Patterson, D., Figlewicz, D. A., Sapp, P., Hentati, A., Donaldson, D., Goto, J., O'regan, J. P., Deng, H. X. \& Et Al. (1993). Mutations in Cu/Zn superoxide dismutase gene are associated with familial amyotrophic lateral sclerosis. Nature, Vol.362, No.6415, (March 1993), pp.59-62, ISSN 0028-0836.

Scaffidi, P., Misteli, T. \& Bianchi, M. E. (2002). Release of chromatin protein HMGB1 by necrotic cells triggers inflammation. Nature, Vol.418, No.6894, (July 2002), pp.191195, ISSN 0028-0836.

Schafer, D. P. \& Stevens, B. (2010). Synapse elimination during development and disease: immune molecules take centre stage. Biochem Soc Trans, Vol.38, No.2, (April 2010), pp.476-481, ISSN 1470-8752.

Sta, M., Sylva-Steenland, R. M., Casula, M., De Jong, J. M., Troost, D., Aronica, E. \& Baas, F. (2011). Innate and adaptive immunity in amyotrophic lateral sclerosis: evidence of complement activation. Neurobiology of disease, Vol.42, No.3, (June 2011), pp.211220, ISSN 1095-953X.

Stevens, B., Allen, N. J., Vazquez, L. E., Howell, G. R., Christopherson, K. S., Nouri, N., Micheva, K. D., Mehalow, A. K., Huberman, A. D., Stafford, B., Sher, A., Litke, A. M., Lambris, J. D., Smith, S. J., John, S. W. \& Barres, B. A. (2007). The classical complement cascade mediates CNS synapse elimination. Cell, Vol.131, No.6, (December 2007), pp.1164-1178, ISSN 0092-8674.

Strong, M. J. (2003). The basic aspects of therapeutics in amyotrophic lateral sclerosis. Pharmacology \& Therapeutics, Vol.98, No.3, (n.d.), pp.379-414, ISSN 01637258.

Tang, S. C., Arumugam, T. V., Xu, X., Cheng, A., Mughal, M. R., Jo, D. G., Lathia, J. D., Siler, D. A., Chigurupati, S., Ouyang, X., Magnus, T., Camandola, S. \& Mattson, M. P. (2007). Pivotal role for neuronal Toll-like receptors in ischemic brain injury and functional deficits. Proceedings of the National Academy of Sciences of the United States of America, Vol.104, No.34, (August 2007), pp.13798-13803, ISSN 0027-8424.

Thoman, M. L., Meuth, J. L., Morgan, E. L., Weigle, W. O. \& Hugli, T. E. (1984). C3d-K, a kallikrein cleavage fragment of $\mathrm{iC} 3 \mathrm{~b}$ is a potent inhibitor of cellular proliferation. Journal of immunology, Vol.133, No.5, (November 1984), pp.2629-2633, ISSN 00221767.

Torres, M. \& Forman, H. J. (1999). Activation of several MAP kinases upon stimulation of rat alveolar macrophages: role of the NADPH oxidase. Arch Biochem Biophys, Vol.366, No.2, (June 1999), pp.231-239, ISSN 0003-9861.

Trbojevic-Cepe, M., Brinar, V., Pauro, M., Vogrinc, Z. \& Stambuk, N. (1998). Cerebrospinal fluid complement activation in neurological diseases. Journal of the neurological sciences, Vol.154, No.2, (February 1998), pp.173-181, ISSN 0022-510X.

Tsai, H. R., Yang, L. M., Tsai, W. J. \& Chiou, W. F. (2004). Andrographolide acts through inhibition of ERK1/2 and Akt phosphorylation to suppress chemotactic migration. Eur J Pharmacol, Vol.498, No.1-3, (September 2004), pp.45-52, ISSN 0014-2999. 
Tsuboi, Y. \& Yamada, T. (1994). Increased concentration of C4d complement protein in CSF in amyotrophic lateral sclerosis. Journal of neurology, neurosurgery, and psychiatry, Vol.57, No.7, (July 1994), pp.859-861, ISSN 0022-3050.

Van Beek, J., Elward, K. \& Gasque, P. (2003). Activation of complement in the central nervous system: roles in neurodegeneration and neuroprotection. Ann $N$ Y Acad Sci, Vol.992, (May 2003), pp.56-71, ISSN 0077-8923.

Van Lith, L. H., Oosterom, J., Van Elsas, A. \& Zaman, G. J. (2009). C5a-stimulated recruitment of beta-arrestin2 to the nonsignaling 7-transmembrane decoy receptor C5L2. J Biomol Screen, Vol.14, No.9, (October 2009), pp.1067-1075, ISSN 1552-454X.

Wong, A. K., Finch, A. M., Pierens, G. K., Craik, D. J., Taylor, S. M. \& Fairlie, D. P. (1998). Small molecular probes for G-protein-coupled C5a receptors: conformationally constrained antagonists derived from the $\mathrm{C}$ terminus of the human plasma protein C5a. Journal of medicinal chemistry, Vol.41, No.18, (August 1998), pp.3417-3425, ISSN 0022-2623.

Woodruff, T. M., Ager, R. R., Tenner, A. J., Noakes, P. G. \& Taylor, S. M. (2010). The role of the complement system and the activation fragment $\mathrm{C} 5 \mathrm{a}$ in the central nervous system. Neuromolecular Med, Vol.12, No.2, (June 2010), pp.179-192, ISSN 1559-1174.

Woodruff, T. M., Arumugam, T. V., Shiels, I. A., Reid, R. C., Fairlie, D. P. \& Taylor, S. M. (2003). A potent human C5a receptor antagonist protects against disease pathology in a rat model of inflammatory bowel disease. J Immunol, Vol.171, No.10, (Nov ember 2003), pp.5514-5520, ISSN 0022-1767.

Woodruff, T. M., Costantini, K. J., Crane, J. W., Atkin, J. D., Monk, P. N., Taylor, S. M. \& Noakes, P. G. (2008a). The complement factor C5a contributes to pathology in a rat model of amyotrophic lateral sclerosis. J Immunol, Vol.181, No.12, (Dec ember 2008), pp.8727-8734, ISSN 1550-6606.

Woodruff, T. M., Costantini, K. J., Taylor, S. M. \& Noakes, P. G. (2008b). Role of complement in motor neuron disease: animal models and therapeutic potential of complement inhibitors. Adv Exp Med Biol, Vol.632, (November 2008), pp.143-158, ISSN 00652598.

Woodruff, T. M., Crane, J. W., Proctor, L. M., Buller, K. M., Shek, A. B., De Vos, K., Pollitt, S., Williams, H. M., Shiels, I. A., Monk, P. N. \& Taylor, S. M. (2006). Therapeutic activity of C5a receptor antagonists in a rat model of neurodegeneration. FASEB J, Vol.20, No.9, (July 2006), pp.1407-1417, ISSN 1530-6860.

Woodruff, T. M., Nandakumar, K. S. \& Tedesco, F. (2011). Inhibiting the C5-C5a receptor axis. Molecular immunology, Vol.48, No.14, (August 2011), pp.1631-1642, ISSN 18729142.

Woodruff, T. M., Pollitt, S., Proctor, L. M., Stocks, S. Z., Manthey, H. D., Williams, H. M., Mahadevan, I. B., Shiels, I. A. \& Taylor, S. M. (2005). Increased potency of a novel complement factor 5 a receptor antagonist in a rat model of inflammatory bowel disease. J Pharmacol Exp Ther, Vol.314, No.2, (August 2005), pp.811-817, ISSN 00223565.

Woodruff, T. M., Strachan, A. J., Dryburgh, N., Shiels, I. A., Reid, R. C., Fairlie, D. P. \& Taylor, S. M. (2002). Antiarthritic activity of an orally active C5a receptor antagonist against antigen-induced monarticular arthritis in the rat. Arthritis Rheum, Vol.46, No.9, (September 2002), pp.2476-2485, ISSN 0004-3591. 
Worms, P. M. (2001). The epidemiology of motor neuron diseases: a review of recent studies. Journal of the neurological sciences, Vol.191, No.1-2, (October 2001), pp.3-9, ISSN 0022-510X.

Zhao, W., Beers, D. R., Henkel, J. S., Zhang, W., Urushitani, M., Julien, J. P. \& Appel, S. H. (2010). Extracellular mutant SOD1 induces microglial-mediated motoneuron injury. Glia, Vol.58, No.2, (January 2010), pp.231-243, ISSN 1098-1136. 
AMYOTROPHIC

LATERAL SCLEROSIS

Eaced by Marton H. maver

\section{Amyotrophic Lateral Sclerosis}

Edited by Prof. Martin Maurer
ISBN 978-953-307-806-9

Hard cover, 718 pages

Publisher InTech

Published online 20, January, 2012

Published in print edition January, 2012

Though considerable amount of research, both pre-clinical and clinical, has been conducted during recent years, Amyotrophic Lateral Sclerosis (ALS) remains one of the mysterious diseases of the 21st century. Great efforts have been made to develop pathophysiological models and to clarify the underlying pathology, and with novel instruments in genetics and transgenic techniques, the aim for finding a durable cure comes into scope. On the other hand, most pharmacological trials failed to show a benefit for ALS patients. In this book, the reader will find a compilation of state-of-the-art reviews about the etiology, epidemiology, and pathophysiology of ALS, the molecular basis of disease progression and clinical manifestations, the genetics familial ALS, as well as novel diagnostic criteria in the field of electrophysiology. An overview over all relevant pharmacological trials in ALS patients is also included, while the book concludes with a discussion on current advances and future trends in ALS research.

\section{How to reference}

In order to correctly reference this scholarly work, feel free to copy and paste the following:

John D. Lee, Jia Y. Lee, Stephen M. Taylor, Peter G. Noakes and Trent M. Woodruff (2012). Innate Immunity in ALS, Amyotrophic Lateral Sclerosis, Prof. Martin Maurer (Ed.), ISBN: 978-953-307-806-9, InTech, Available from: http://www.intechopen.com/books/amyotrophic-lateral-sclerosis/innate-immunity-in-als

\section{INTECH}

open science | open minds

\author{
InTech Europe \\ University Campus STeP Ri \\ Slavka Krautzeka 83/A \\ 51000 Rijeka, Croatia \\ Phone: +385 (51) 770447 \\ Fax: +385 (51) 686166 \\ www.intechopen.com
}

\author{
InTech China \\ Unit 405, Office Block, Hotel Equatorial Shanghai \\ No.65, Yan An Road (West), Shanghai, 200040, China \\ 中国上海市延安西路65号上海国际贵都大饭店办公楼 405 单元 \\ Phone: +86-21-62489820 \\ Fax: +86-21-62489821
}


(C) 2012 The Author(s). Licensee IntechOpen. This is an open access article distributed under the terms of the Creative Commons Attribution 3.0 License, which permits unrestricted use, distribution, and reproduction in any medium, provided the original work is properly cited. 